\title{
Testosterone and Gonadotropins in Infertile Men with Sertoli Cell Only Syndrome from Gaza Strip
}

\author{
MAGED M. YASSIN, ${ }^{1}$ ABDEL MONEM H. LUBBAD, ${ }^{1}$ AHMED Z TAHA, ${ }^{2}$ MOHAMMED M. LAQQAN ${ }^{1}$, SAMAR M. \\ ABU JAMIEA ${ }^{1}$
}

\begin{abstract}
Aim: To assess serum testosterone and gonadotropins in Sertoli cell only syndrome patients from Gaza Strip.

Methods: Based on testicular biopsy, a cross section of 74 Sertoli cell only syndrome patients were enrolled in the study. Age matched 44 fertile men were served as controls. Patients and controls were questioned for their medical history. Blood samples were drawn and serum testosterone, luteinizing hormone (LH), and follicle stimulating hormone (FSH) were determined by enzyme-linked immunosorbent assay. Data were computer analyzed using SPSS/PC, version 18.0.

Results: Varicocele and hormonal problems were significantly more frequent among patients than controls $(P<0.05)$. Serum testosterone was significantly lower in patients compared to controls $(I .7 \pm I .3$ versus $5.0 \pm 2.2 \mathrm{ng} / \mathrm{ml}, P=0.000$ ). In contrast, LH and FSH were significantly higher in patients than controls (I2.8 \pm 9.7 and $20.8 \pm 14.8 \mathrm{~m} / \mathrm{U} / \mathrm{ml}$ versus $6.3 \pm 3.1$ and $7.7 \pm 3.9 \mathrm{~m} / \mathrm{U} / \mathrm{ml}, P=0.000$, respectively). Hypergonadotrophic hypogonadism and hypogonadotrophic hypogonadism patients showed lower levels of testosterone compared to the normal reference value $(0.9 \pm 0.5$ and $0.5 \pm 0.4 \mathrm{ng} / \mathrm{ml}$ versus $2.0-7.0 \mathrm{ng} / \mathrm{ml})$. Higher levels of $\mathrm{LH}$ and $\mathrm{FSH}$ were recorded in hypergonadotrophic hypogonadism $(24.5 \pm 2.6$ and $37.4 \pm 6.7 \mathrm{~m} / \mathrm{U} / \mathrm{ml})$ compared to the reference values of 2.0-13.0 and 2.5-10.0 m/U/ml, respectively whereas $L H$ and FSH levels were lower in hypogonadotrophic hypogonadism $(0.6 \pm 0.4$ and $0.6 \pm 0.5 \mathrm{~m} / \mathrm{U} / \mathrm{ml}$, respectively). In this context, all hypergonadotrophic hypogonadism and hypogonadotrophic hypogonadism patients showed abnormal levels of testosterone, $\mathrm{LH}$ and FSH.

Conclusions: Abnormal levels of serum testosterone, $\mathrm{LH}$ and FSH, particularly in hypergonadotrophic hypogonadism and hypogonadotrophic hypogonadism were identified in infertile men with Sertoli cell only syndrome from Gaza Strip.
\end{abstract}

Keywords: Infertility, Sertoli cell only, testosterone, gonadotropins, Gaza Strip.

\section{Introduction}

One of the important issues contributing to male infertility is azoospermia which is defined as the absence of sperm in at least two different ejaculate samples, including the centrifuged sediment. ${ }^{1}$ The etiology of azoospermia may be attributed to 1) pre-testicular causes e.g. endocrine abnormalities causing secondary testicular failure, 2) testicular causes e.g. primary testicular failure due to intrinsic disorders of spermatogenesis within the testis, including maturation arrest and complete absence of germ cells or Sertoli cell only syndrome or 3) post testicular causes e.g.

1. Faculty of Medicine, The Islamic University of Gaza, Gaza Strip, Palestine.

2. Department of Medical Technology, Faculty of Science, The Islamic University of Gaza, Gaza Strip, Palestine.

Corresponding author: Dr. Maged M. Yassin, Professor of Physiology, Department of Physiology, Faculty of Medicine, The Islamic University of Gaza, P.O. Box 108, Remal, Gaza Strip, Palestine. Tel: +970 (8) 2860700. Fax: +970 (8) 2860800. E-mail: myassin@iugaza.edu.ps ejaculatory dysfunction or ductal obstruction that prevent sperm transport. ${ }^{2}$

Sertoli cell only syndrome or germ cell aplasia is one of the etiologic categories of non-obstructive azoospermia that applies to a testicle in which germ cells at any stage of maturation are absent, but the tubular architecture is not effaced by fibrosis and supporting cells continue to be present. ${ }^{3}$ Examples of causes of Sertoli cell only syndrome may include genetic factors, hormonal factors, idiopathic factors, varicocele, toxin exposure, history of radiation therapy, and history of severe trauma. ${ }^{4-6}$

Endocrine malfunctions are more prevalent in infertile men than in the general population, but still quite uncommon. Abnormalities of the hypothalamic-pituitary-testicular axis at the testicular level cause primary testicular failure, whereas central defects of the hypothalamus or pituitary cause secondary testicular failure. Hypergonadotropic hypogonadism results in low testosterone levels, impairment of spermatogenesis and elevated gonadotropin levels. 
Hypogonadotropic hypogonadism results in low testosterone levels, impairment of spermatogenesis and low or lownormal gonadotropin levels. ${ }^{7,8}$

Research carried out on azoospermia in Gaza strip is very limited. To our knowledge, only two recent studies published; one addressed screening for Y chromosome microdeletions in a population of infertile males ${ }^{9}$ and the other study handled hormonal and histological aspects among infertile men in Gaza strip. ${ }^{10}$ However, the present study focused specifically on testosterone and gonadotropin hormones in infertile men with Sertoli cell only syndrome from Gaza Strip. Therefore, the present study provided more information on endocrine profile of Sertoli cell only syndrome and highlighted an extraordinary public health problem of high concern for couples seeking children in Gaza Strip.

\section{Subjects and Methodology Subjects}

Based on testicular biopsy, a cross section of 74 infertile men with Sertoli cell only syndrome (patients) visiting the Specialized Medical Centers in Gaza strip were enrolled in the present study. They have the history of at least 3 years duration of infertility. ${ }^{11}$ Semen analysis was also performed to confirm azoospermia based on World Health Organization criteria. ${ }^{1}$ A total number of 44 controls were selected at the basis of being married with at least one child and sperm count $>20$ million sperm $/ \mathrm{ml}$. Patients and controls were age matched. Ethical approval was provided by Helsinki committee at the Palestinian Ministry of Health and all participants gave an informed consent. Patients and controls were questioned for their medical history.

\section{Testicular biopsy}

Incision biopsy was taken by physician, from bilateral testes, then pre solved in Bouin's solution as a fixative reagent. ${ }^{12}$ Following fixation, dehydration of fixed tissues was done through ascending grades of ethyl alcohol (50\%, 70\%, 90\%, $95 \%$ and absolute alcohol). Tissues were then cleared with xylene. This was followed by impregnation with paraffin wax. Having been completely impregnated, the tissues were embedded in paraffin wax, sectioned by a rotary microtome at a thickness of $3 \frac{1}{4} \mathrm{~m}$, mounted and affixed to slides. Sections were then stained as a routine in harris's alum haematoxylin and eosin.

\section{Blood sampling and processing}

Venous blood samples were drawn by a well-trained medical technologist into vacutainer tubes from patients and controls.
Blood was left for a while without anticoagulant to allow blood to clot. Then, serum samples were obtained by centrifugation at room temperature at $3000 \mathrm{rpm} / 10$ minutes for hormonal assay. Testosterone, LH and FSH levels were determined by enzyme-linked immunosorbent assay, TECO kit, USA.

\section{Statistical analysis}

Data were computer analyzed using SPSS/PC (Statistical Package for the Social Science Inc. Chicago, Illinois USA, version 18.0) statistical package. Simple distribution of the study variables and the cross tabulation were applied. Yates's continuity correction test, $\chi^{2}$ (corrected), was used as not more than $20 \%$ of the cells had an expected frequency of less than five and the expected numbers were small. The independent sample t-test procedure was used to compare means of quantitative variables by the separated cases into two qualitative groups such as the relationship between patients and controls hormones. Percent difference $=(|(\mathrm{V} 1-\mathrm{V} 2)| /$ $((\mathrm{V} 1+\mathrm{V} 2) / 2)) * 100$. The one-way ANOVA test was applied. The results were accepted as statistical significant when the $\mathrm{p}$-value was less than $5 \%(\mathrm{P}<0.05)$.

\section{Results}

Medical history of the study population

The mean age of patients $(n=74)$ and controls $(n=44)$ were $29.8 \pm 5.9$ and $30.2 \pm 5.7$ years, respectively. Medical history revealed that varicocele was significantly more prevalent among patients compared to controls $12(16.2 \%)$ versus 1 $(2.3 \%), \chi_{\text {(corrected) }}^{2}=4.142$ and $\mathrm{P}=0.042$. Similarly, hormonal problems were significantly higher in patients than controls $19(25.7 \%)$ versus $2(4.5 \%), \chi^{2}$ (corrected) $=7.039$ and $\mathrm{P}=0.008$. Although trauma was more frequent among patients, the difference between patients and controls was not significant $9(12.2 \%)$ versus $2(4.5 \%), \chi^{2}$ (corrected) $=1.120$ and $\mathrm{P}=0.294$.

Testosterone and gonadotropins levels of the study population

As illustrated in Table I, the mean level of testosterone was significantly lower in patients compared to controls with percentage difference of $98.5 \%$ ( $1.7 \pm 1.3$ versus $5.0 \pm 2.2 \mathrm{ng} /$ $\mathrm{ml}, \mathrm{t}=10.054, \mathrm{P}=0.000)$. In contrast, the mean levels of $\mathrm{LH}$ and FSH were significantly higher in patients compared to controls showing percentage differences of $68.1 \%$ and $91.9 \%$, respectively $(12.8 \pm 9.7$ and $20.8 \pm 14.8 \mathrm{mlU} / \mathrm{ml}$ versus $6.3 \pm 3.1$ and $7.7 \pm 3.9 \mathrm{mlU} / \mathrm{ml}, \mathrm{t}=4.352$ and $\mathrm{t}=5.708, \mathrm{P}=0.000$, respectively). 
Table-I

Testosterone and gonadotropins levels of the study population

\begin{tabular}{lccccc}
\hline Hormone & $\begin{array}{c}\text { Patients } \\
(\mathrm{n}=74)\end{array}$ & $\begin{array}{c}\text { Controls } \\
(\mathrm{n}=44)\end{array}$ & $\begin{array}{c}\% \\
\text { Difference }\end{array}$ & $\mathrm{t}$ & $\begin{array}{c}\text { P- } \\
\text { value }\end{array}$ \\
\hline Testosterone (ng/ml) & $1.7 \pm 1.3$ & $5.0 \pm 2.2$ & 98.5 & 10.054 & 0.000 \\
Range (min-max) & $(0.03-6.1)$ & $(1.9-11.7)$ & & & \\
$*$ LH $(\mathrm{mIU} / \mathrm{ml})$ & $12.8 \pm 9.7$ & $6.3 \pm 3.1$ & 68.1 & 4.352 & 0.000 \\
Range $(\min -\mathrm{max})$ & $(0.1-31.2)$ & $(1.1-11.8)$ & & & \\
$* *$ FSH (mIU/ml) & $20.8 \pm 14.8$ & $7.7 \pm 3.9$ & 91.9 & 5.708 & 0.000 \\
Range (min-max) & $(0.1-48.0)$ & $(2.5-16.1)$ & & & \\
\hline
\end{tabular}

*LH: Luteinizing hormone, **FSH: Follicle stimulating hormone. Reference values: Testosterone 2.0-7.0 ng/ml, LH 2.0$13.0 \mathrm{mIU} / \mathrm{ml}$, FSH 2.5-10.0 mIU/ml. All values are expressed as mean $\pm \mathrm{SD}$. $\mathrm{P}<0.05$ : Significant.

Testosterone and gonadotropins of different aspects of Sertoli cell only patients

As indicated in Table II, ANOVA test showed significant change among different diagnostic aspects of Sertoli cell only syndrome for each particular hormone $(\mathrm{P}=0.000)$. Lower levels of testosterone were found in hypergonadotrophic hypogonadism and hypogonadotrophic hypogonadism compared to the normal reference value $(0.9 \pm 0.5$ and $0.5 \pm 0.4$ versus $2.0-7.0 \mathrm{ng} / \mathrm{ml})$. In primary testicular failure and idiopathy testosterone levels were in the range of normal reference value. Higher levels of LH and $\mathrm{FSH}$ were recorded in primary testicular failure (17.3 \pm 6.1 and $28.9 \pm 6.3 \mathrm{mlU} / \mathrm{ml}$, respectively) as well as in hypergonadotrophic hypogonadism $(24.5 \pm 2.6$ and $37.4 \pm 6.7$ $\mathrm{mlU} / \mathrm{ml}$, respectively) compared to the reference values of 2.0-13.0 and 2.5-10.0 $\mathrm{mlU} / \mathrm{ml}$, respectively. In contrast, LH and FSH levels were lower in hypogonadotrophic hypogonadism $(0.6 \pm 0.4$ and $0.6 \pm 0.5 \mathrm{mlU} / \mathrm{ml}$, respectively). In idiopathy, $\mathrm{LH}$ and $\mathrm{FSH}$ levels were in the range of normal reference values.
Normal and abnormal testosterone and gonadotropins levels of different aspects of Sertoli cell only patients

As indicated in Table III, the number of primary testicular failure, hypergonadotrophic hypogonadism, hypogonadotrophic hypogonadism and idiopathic patients showing abnormal levels of testosterone were 18 (45.0\%), 9 (100\%), $14(100 \%)$ and $3(27.3 \%)$, respectively compared to 22 (55.0\%), $0(0.0 \%), 0(0.0 \%)$ and $8(72.7 \%)$ patients with normal levels of the hormone $\left(\chi^{2}\right.$ (corrected) $=18.890$ and $\mathrm{P}=0.000)$. Abnormal levels of $\mathrm{LH}$ were exhibited by 30 (75.0\%), $9(100 \%)$ and $14(100 \%)$ and $4(36.4 \%)$ patients, respectively versus $10(25.0 \%), 0(0.0 \%), 0(0.0 \%)$ and 7 $(63.6 \%)$ patients with normal levels $\left(\chi^{2}\right.$ (corrected) $^{2}=12.644$ and $\mathrm{P}=0.005$ ). For FSH, all primary testicular failure, hypergonadotrophic hypogonadism, hypogonadotrophic hypogonadism patients as well as $4(36.4 \%)$ idiopathic patients showed abnormal levels of the hormone $\left(\chi^{2}\right.$ (corrected) $=35.512$ and $\mathrm{P}=0.000$ ).

Table-II

Testosterone and gonadotropins levels of different aspects of Sertoli cell only patients

\begin{tabular}{lcccccc}
\hline Hormone & $\begin{array}{c}\text { 1ry TF } \\
(\mathrm{n}=40)\end{array}$ & $\begin{array}{c}\text { Hyper } \\
\text { hypo } \\
(\mathrm{n}=9)\end{array}$ & $\begin{array}{c}\text { Hypo } \\
\text { hypo } \\
(\mathrm{n}=14)\end{array}$ & $\begin{array}{c}\text { Idiopathy } \\
(\mathrm{n}=11)\end{array}$ & $\begin{array}{c}\text { P- } \\
\text { value }\end{array}$ \\
\hline Testosterone $(\mathrm{ng} / \mathrm{ml})$ & $2.2 \pm 1.3$ & $0.9 \pm 0.5$ & $0.5 \pm 0.4$ & $2.4 \pm 1.0$ & 12.135 & 0.000 \\
*LH $(\mathrm{mIU} / \mathrm{ml})$ & $17.3 \pm 6.1$ & $24.5 \pm 2.6$ & $0.6 \pm 0.4$ & $2.6 \pm 1.5$ & 79.794 & 0.000 \\
**FSH $(\mathrm{mIU} / \mathrm{ml})$ & $28.9 \pm 6.3$ & $37.4 \pm 6.7$ & $0.6 \pm 0.5$ & $3.5 \pm 1.6$ & 167.415 & 0.000 \\
\hline
\end{tabular}

*LH: Luteinizing hormone, **FSH: Follicle stimulating hormone, 1ry TF: Primary testicular failure, Hyper hypo: Hypergonadotrophic hypogonadism, Hypo hypo: Hypogonadotrophic hypogonadism. Reference values: Testosterone 2.0-7.0 ng/ml, Lutenizing hormone 2.0$13.0 \mathrm{mlU} / \mathrm{ml}$, Follicle stimulating hormone $2.5-10.0 \mathrm{mlU} / \mathrm{ml}$. All values expressed as mean $\pm \mathrm{SD}, \mathrm{P}<0.05$ : Significant. 
Table-III

Normal and abnormal testosterone and gonadotropins levels of different aspects of Sertoli cell only patients in Gaza Strip

\begin{tabular}{|c|c|c|c|c|c|c|}
\hline Hormone & $\begin{array}{l}\text { 1ry TF } \\
(\mathrm{n}=40)\end{array}$ & $\begin{array}{l}\text { Hyper } \\
\text { hypo } \\
(\mathrm{n}=9)\end{array}$ & $\begin{array}{c}\text { Hypo } \\
\text { hypo } \\
(\mathrm{n}=14)\end{array}$ & $\begin{array}{l}\text { Idiopathic } \\
(\mathrm{n}=11)\end{array}$ & $c^{2}$ & $\begin{array}{c}\mathrm{P}- \\
\text { value }\end{array}$ \\
\hline Testosterone (ng/ml) & No. $(\%)$ & No. $(\%)$ & No. $(\%)$ & No. (\%) & & \\
\hline Normal & $22(55.0)$ & $0(0.0)$ & $0(0.0)$ & $8(72.7)$ & 18.890 & 0.000 \\
\hline Abnormal & $18(45.0)$ & $9(100)$ & $14(100)$ & $3(27.3)$ & & \\
\hline \multicolumn{7}{|l|}{ *LH (mlU/ml) } \\
\hline Normal & $10(25.0)$ & $0(0.0)$ & $0(0.0)$ & $7(63.6)$ & 12.644 & 0.005 \\
\hline Abnormal & $30(75.0)$ & $9(100)$ & $14(100)$ & $4(36.4)$ & & \\
\hline \multicolumn{7}{|l|}{ **FSH (mlU/ml) } \\
\hline Normal & $0(0.0)$ & $0(0.0)$ & $0(0.0)$ & $7(63.6)$ & 35.512 & 0.000 \\
\hline Abnormal & $40(100)$ & $9(100)$ & $14(100)$ & $4(36.4)$ & & \\
\hline
\end{tabular}

*LH: Luteinizing hormone, **FSH: Follicle stimulating hormone, 1ry TF: Primary testicular failure, Hyper hypo: Hypergonadotrophic hypogonadism, Hypo hypo: Hypogonadotrophic hypogonadism; Reference values: Testosterone 2.0-7.0 ng/ml, Lutenizing hormone 2.0$13.0 \mathrm{mlU} / \mathrm{ml}$, Follicle stimulating hormone 2.5-10.0 mlU/ml. P-value of c2 (corrected) test, $\mathrm{P}<0.05$ : Significant.

\section{Discussion}

Male infertility is a reproductive health problem that is poorly studied and understood. Worldwide, male infertility contributes to more than half of all cases of childlessness and it is argued that male infertility may be particularly problematic for Middle Eastern men in their societies; there, both virility and fertility are typically tied to manhood. Thus, male infertility is a potentially emasculating condition, surrounded by secrecy and stigma. ${ }^{13,14}$ In this context, there are under-reporting or even no real figures on male infertility in Gaza Strip. Therefore, the present study targeted Sertoli cell only syndrome as one of the etiologies of azoospermia focusing on testosterone and gonadotropins in infertile men from Gaza Strip.

The mean age of the patients in the present study (29.8 years) was lower than that reported from Nigerian (35.7 years) and Kenyan (36.1 years) studies. ${ }^{15,16}$ The younger age of our patient sample could be explained on the basis that most men seeking out to have children at young age immediately after marriage. Medical history showed that varicocele was significantly more prevalent among patients compared to controls. This coincides with the idea that varicocele contributes to male infertility. ${ }^{17,18}$ The proposed pathophysiologic mechanisms by which varicocele impairs male fertility may include hypoxia and stasis, elevated testicular temperature, reflux of adrenal catecholamines, and increased oxidative stress. ${ }^{19}$ Hormonal problems were also significantly higher in patients than controls implying that
Sertoli cell only syndrome is associated with hormonal disturbances. ${ }^{20}$

Hormonal profile of the study population showed that the mean level of testosterone was significantly lower in patients compared to controls. Such decline in testosterone levels in patients may be explained on the basis of hypogonadism which is characterized by a deficiency or absence of Leydig cell function in production of testosterone. ${ }^{21,22}$ In contrast, the mean levels of LH and FSH were significantly elevated in patients compared to controls. Such result is in accordance with other studies. ${ }^{16,23}$ In the infertile men, higher concentration of FSH is considered to be a reliable indicator of germinal epithelial damage, and was shown to be associated with azoospermia and severe oligozoospermia. ${ }^{24}$

The clinical picture of Sertoli cell only syndrome aspects in infertile men in Gaza Strip showed marked lower levels of testosterone in hypergonadotrophic hypogonadism and hypogonadotrophic hypogonadism compared to the normal reference value. Similar results were previously reported. ${ }^{25,26}$ Higher levels of LH and FSH were recorded in primary testicular failure and hypergonadotrophic hypogonadism whereas their levels were obviously lower in hypogonadotrophic hypogonadism compared to the reference values. Male hypergonadotropic hypogonadism is characterized by hypogonadism due to an impaired response of the testes to LH and FSH, and in turn a lack of testosterone production and elevated gonadotropin levels as an attempt of compensation by the body. ${ }^{21,27}$ In male hypogonadotropic 
hypogonadism there is inadequate secretion of hypothalamic gonadotropin releasing hormone and lack of production of pituitary gonadotropins and in turn lack of testosterone production. ${ }^{22,28}$

As depicted from data presented in this study, all infertile men with hypergonadotrophic hypogonadism and hypogonadotrophic hypogonadism showed abnormal levels of testosterone, $\mathrm{LH}$ and FSH in comparison with their normal reference values. Such findings supported the above mentioned results that abnormal low levels of testosterone were recorded in both hypergonadotrophic hypogonadism and hypogonadotrophic hypogonadism as well as high and low abnormal levels of LH and FSH were found in hypergonadotrophic hypogonadism and hypogonadotrophic hypogonadism respectively, and coincided with that previously reported. ${ }^{16,29}$

\section{Conclusion}

Serum testosterone was significantly lower in patients than controls, whereas LH and FSH were significantly higher in patients. Abnormal lower levels of testosterone were found in hypergonadotrophic hypogonadism and hypogonadotrophic hypogonadism compared to the normal reference value. Higher levels of LH and FSH were recorded in hypergonadotrophic hypogonadism, whereas LH and FSH levels were lower in hypogonadotrophic hypogonadism compared to the reference values.

\section{Conflict of interest: None.}

\section{References}

1. World Health Organization. WHO laboratory manual for the examination and processing of human semen. 5 th ed. Geneva: World Health Organization; 2010.

2. Yildiz-Aktas IZ, Monaco SE, Khalbuss WE, Parwani AV, Jaffe TM, Pantanowitz L. Testicular touch preparation cytology in the evaluation of male infertility. CytoJournal 2011;8(24):1-7.

3. Jain M, Halder A. Sertoli cell only syndrome: Status of sertoli cell maturation and function. Indian $\mathrm{J}$ Endocr Metab 2012;16(S2):S512-513.

4. Esteves S, Miyaoka R, Agarwal A. An update on the clinical assessment of the infertile male. Clinics 2011;66(4):691-700.

5. Aksglaede L, Juul A. Testicular function and fertility in men with Klinefelter syndrome. Eur J Endocrinol 2013;168(4):R67-76.

6. Ustuner M, Yilmaz H, Yavuz U, Ciftci S, Saribacak A, Aynur BS, et al. Varicocele repair improves testicular histology in men with non-obstructive azoospermia. Biomed Res Int 2015;1-5.
7. Bhasin S, Cunningham GR, Hayes FJ, Matsumoto AM, Snyder PJ, Swerdloff RS, et al. Testosterone therapy in men with androgen deficiency syndromes: an Endocrine Society clinical practice guideline. J Clin Endocrinol Metab 2010;95 (6):2536-2559.

8. Gudeloglu A, Parekattil SJ. Update in the evaluation of the azoospermic male. Clinics 2013;68(S1):27-34.

9. Shaqalaih AJ, Abu Halima MS, Ashour MJ, Sharif FA. Screening for Y-chromosome microdeletions in a population of infertile males in the Gaza Strip. J Exp Clin Assist Reprod 2009;6(7):1-9.

10. Lubbad A. Hormonal and histological aspects of germ cell aplasia among a group of infertile men in Gaza Strip. IUGNES 2015;23(1):55-62.

11. Babu SR, Sadhnani MD, Swarna M, Padmavathi P, Reddy PP. Evaluation of FSH, LH and testosterone levels in different subgroups of infertile males. Indian J Clin Biochem 2004;19:45-49.

12. Dohle GR, Elzanaty S, van Casteren NJ. Testicular biopsy: clinical practice and interpretation. Asian J Androl 2012;14:88-93.

13. Inhorn MC. Middle Eastern masculinities in the age of new reproductive technologies: male infertility and stigma in Egypt and Lebanon. Med Anthropol Quart 2004;18:34-54.

14. Inhorn MC, Patrizio P. Infertility around the globe: new thinking on gender, reproductive technologies and global movements in the 21 st century. Hum Reprod Update 2015;21(4):411-426.

15. Muthuuri JM. Male infertility in a private Kenyan hospital. East Afr Med J 2005;82:362-366.

16. Geidam A, Yawe K, Adebayo A, Idrisa A. Hormonal profile of men investigated for infertility at the University of Maiduguri in northern Nigeria. Singapore Med J 2008;49:538-541.

17. Karavolos S, Stewart J, Evbuomwan I, McEleny K, Aird I. Assessment of the infertile male. Obstet Gynecol 2013;15:19.

18. Üçer O, Gümü_B. Varicocele in male infertility: current status of surgery techniques. EMJ Repro 2015;1(1):59-64.

19. Krishna Reddy SV. Varicocele and male infertility: Current issues in management-A Review. Med Surg Urol 2014;3(2):137-142.

20. Esteves SC. Male infertility due to spermatogenic failure: current management and future perspectives. Anim Reprod 2015;12(1):62-80.

21. Fraietta R, Zylberstejn DS, Esteves SC. Hypogonadotropic hypogonadism revisited. Clinics 2013;68(S1):81-88. 
22. Wynia B, Kaminetsky JC. Current and emerging testosterone therapies for male hypogonadism. Res Rep Endocr Disord 2015;5:59-69.

23. Nieschlag E, Behre HM, Nieschlag S. Andrology: Male Reproductive Health and Dysfunction $3^{\text {rd }}$ ed. Berlin Heidelberg: Springer-Verlag; 2010.

24. Bergmann M, Behre H, Nieschlag E. Serum FSH and testicular morphology in male infertility. Clin Endocrinol 2008;40:133-136.

25. Farshchi H, Shahnazi A, Azizi F. Effects of testosterone and gonadotropin therapy in men with hypogonadotropic hypogonadism. Int J Endocrinol Metab 2009;4:242-247.
26. Young J. Approach to the male patient with congenital hypogonadotropic hypogonadism. J Clin Endocrinol Metab 2012;97(3):707-718.

27. Darby E, Anawalt BD. Male hypogonadism: an update on diagnosis and treatment. Treat Endocrinol 2005;4(5):293309.

28. Han TS, Bouloux PM. What is the optimal therapy for young males with hypogonadotropic hypogonadism? Clin Endocrinol (Oxf) 2010;72(6):731-737.

29. Dandona P, Rosenberg MT. A practical guide to male hypogonadism in the primary care setting. Int J Clin Pract 2010;64(6):682-696. 